\title{
Macrobenthos of the subtidal Wadden Sea: revisited after 55 years
}

\author{
W. Riesen \& K. Reise \\ II. Zoologisches Institut der Universität Göttingen; D-3400 Göttingen, \\ Federal Republic of Germany \\ and \\ Biologische Anstalt Helgoland (Litoralstation); D-2282 List/Sylt, \\ Federal Republic of Germany
}

\begin{abstract}
During the years 1923-1926 Hagmeier \& Kändler (1927) sampled the macrofauna of subtidal shallows and channels of the Wadden Sea close to the Island of Sylt (German Bight, North Sea). Reinvestigating this study area in 1980, a substantially altered faunal composition was recorded. An approach is made to quantify the comparison in terms of abundance, species richness and diversity of invertebrate taxa. Human interference is assumed to be responsible for the major changes. Natural oyster beds have been overexploited and the local population of Ostrea edulis has been driven to extinction. Subsequently, mussels (Mytilus edulis) spread in the entire region, promoted by shell fishery. Particularly barnacles and many polychaetes took advantage of the expansion of mussel banks which is substantiated by correlation analysis. Reefs of the colonial polychaete Sabellaria spinulosa stood in the way of shrimp trawling and became destroyed together with the associated fauna. A subtidal Zostera marina bed was wiped out in 1934 by a natural epidemic disease but never succeeded in reestablishing itself. The associated fauna disappeared. Large epibenthic predators and scavengers (crabs, snails and starfish) survived all these changềs. The total number of species remained approximately at the same level but molluscs experienced losses and polychaetes diversified. Overall abundance increased with a disproportionately large share of a few species (Mytilus edulis, Balanus crenatus, Cerastoderma edule, Scoloplos armiger). The subtidal fauna of the Wadden Sea proved to be vulnerable to human disturbance; thus, the present community can no longer be viewed as the outcome of entirely natural processes.
\end{abstract}

\section{INTRODUCTION}

An understanding of the benthic ecology of the Wadden Sea necessitates an exploration of its past. Do we have a resilient community in natural balance, a continuously changing assemblage in a hazardous environment, or a pile of organisms disturbed because of repeated human interference? Here we make an attempt to present a comparison of the two quantitative surveys, 55 years apart, on the macrofauna of subtidal shallows and channels to the east of the Island of Sylt. Inspired by C. G. J. Petersen and urged by the declining oyster fishery, Hagmeier started in 1923 a sampling program with dredge and Petersen grab in the North Frisian Wadden Sea (Hagmeier, 1925; Hagmeier \& Kändler, 1927). His sampling scheme and data presentation does not allow a sound, statistically-backed comparison with the present, however, the magnitude of the differences suggests considerable change in species composition and abundance of macrofauna. 


\section{AREA AND METHODS}

The area of investigation is part of the North Frisian Wadden Sea, east of the Island of Sylt. The subtidal benthic fauna is subject to holomarin conditions, soft sediments, and strong tidal currents while the island provides some shelter from the rough North Sea.

Grab samples were taken at 9 sites down the slope of the channel "Lister Ley" and on 2 subtidal shallows once occupied by oyster beds (Fig. 1). Sites on the transect refer to those described by Hagmeier \& Kändler $(1927$, p. 32) as I, II, III, IV, VII, VIII, IX, X, XII with a depth range from $0.5 \mathrm{~m}$ to $18.5 \mathrm{~m}$. Sites in the shallows (depth $3 \mathrm{~m}$ ) correspond to Nos. 36 and 42 on p. 41, hereafter called "Ellenbogen" and "Huntje".

We used a $0.1 \mathrm{~m}^{2}$ Van Veen grab. Quantity and quality of the sediment was recorded. Further treatment of samples was done in the lab. The samples were sieved through a $1 \mathrm{~mm}$ meshed screen in a huge tub. The sieve content was washed into white plastic dishes to pick up the macrofauna. Numbers of more than 100 Balanus crenatus individuals were estimated, colonies of Porifera, Hydrozoa and Bryozoa were noted as present.

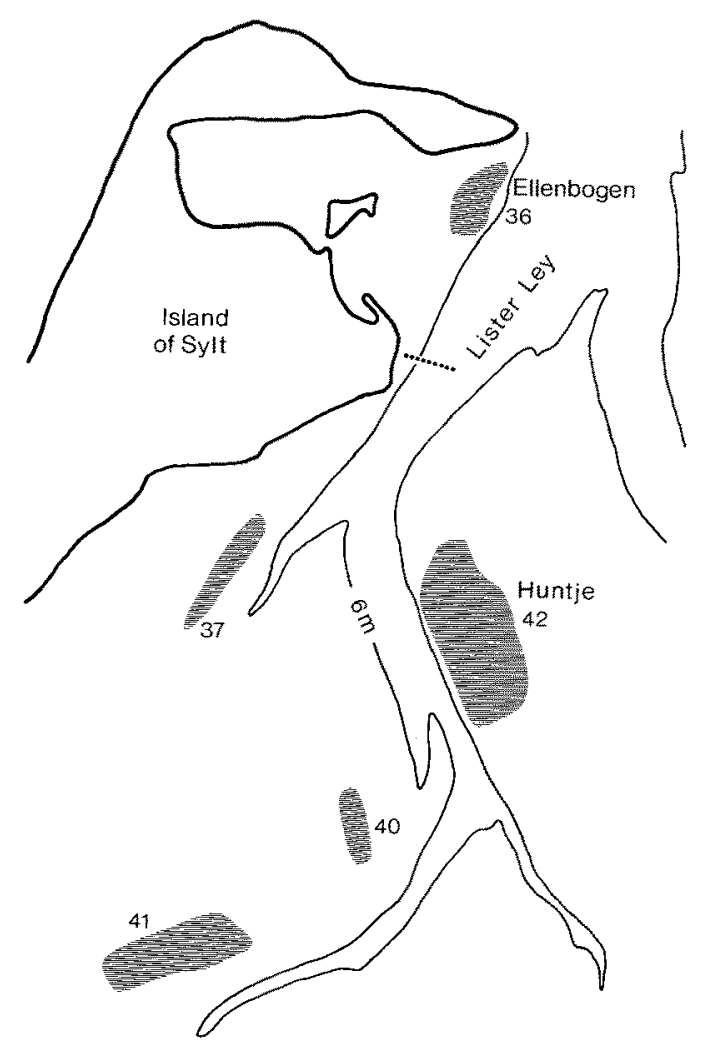

Fig. 1. Wadden Sea of northern Sylt (German Bight), the $6 \mathrm{~m}$-isoline marks the channel system. Former oyster beds are shaded, numbers of stations are from Hagmeier \& Kändler (1927). The dotted line at the western slope of Lister Ley shows the transect with 9 sampling stations investigated in 1923-1926 and in 1980 
In addition to grab samples, dredge hauls were conducted in 5 subtidal shallows including Ellenbogen and Huntje (Fig. 1). The sites correspond to Hagmeier's \& Kändler's Nos. 36, 37, 40, 41 and 42 (p. 44). For the purpose of comparison, the dredge of both authors was rebuilt, with a blade length of $1 \mathrm{~m}$ and a mesh size of $6 \mathrm{~cm}$. Dredge samples were treated qualitatively on board.

\section{RESULTS}

\section{Habitat structure}

In 1980, the sites revisited showed partially altered habitat conditions. In the subtidal shallows, where there were once oyster beds on a sandy bottom, half of the samples contained silty sediment due to silt-assembling mussel banks. Along the transect down the slope of Lister Ley, the same phenomenon occurred at some upper sites, while the sites in the steep part showed signs of erosion. Stones, shell gravel and coarse grained sand occurred. A Zostera marina bed, once in the shallow upper part of the transect, was absent in 1980 and so were reefs of the tube-building polychaete Sabellaria spinulosa on the lower slope (Fig. 2).
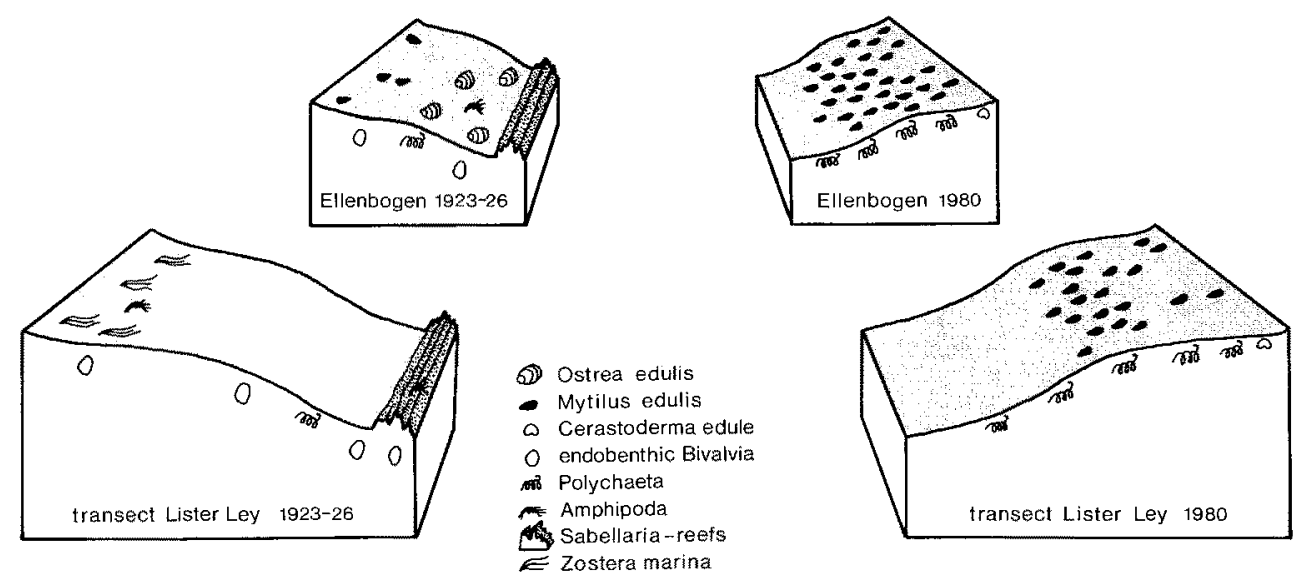

Fig. 2. Cartoon of benthic assemblages in Lister Ley, a comparison between 1923-1926 and 1980 . Block-diagrams above correspond to site 36 and the two below to the dotted transect in Fig. 1

\section{Overall shifts in abundance and species composition}

Most striking is an increase in individuals per area (Fig. 3a). Only two of the sites investigated - both occupied by Sabellaria reefs in 1923-26 - show a decline. Balanus crenatus and Mytilus edulis contributed most to high abundances in 1980. However, even without these two, abundance was generally higher in 1980 because of more polychaetes. 

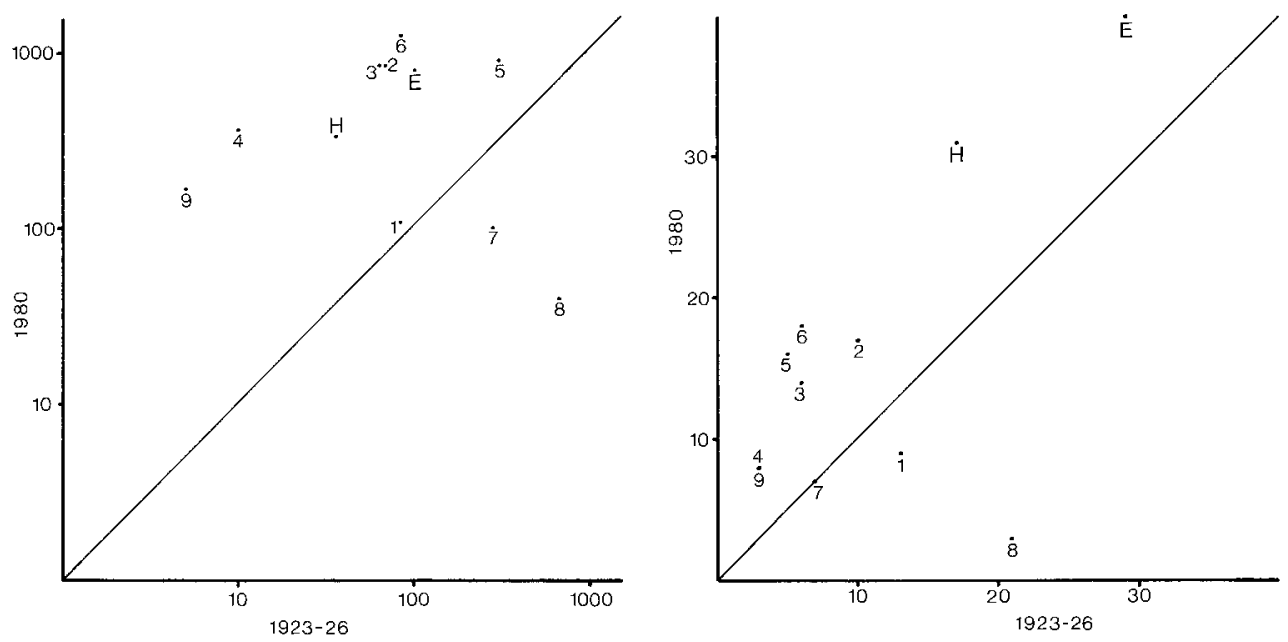

Fig. 3. Comparison between 1923-1926 and 1980 in macrofaunal abundance (logarithmic scale) (left) and in species density (right). Nos 1-9: transect Lister Ley, E = Ellenbogen, H = Huntje. The line at $45^{\circ}$ marks equality between surveys; points above represent higher values in 1980 , points below higher values in 1923-1926. All ratios refer to areas of $0.1 \mathrm{~m}^{2}$, except in (b) where $E=0.9 \mathrm{~m}^{2}$ and $\mathrm{H}=0.4 \mathrm{~m}^{2}$

Ranking of the 8 most abundant species reveals notable changes in dominance since the 1920s (Table 1). Only two species remained in the top ranks until 1980. B. crenatus was able to take advantage of the increased offer of secondary, hard substrate provided by mussel shells. All amphipods abundant during the years 1923-26 were associated with Sabellaria reefs and the Zostera bed. Most of the sites investigated show higher species density in 1980, mainly caused by polychaetes (Fig. 3b). The only sites with a reverse trend are those of former Sabellaria reefs and Zostera beds, where a formerly rich epifauna has gone.

While abundance and species density increased at most sites, the total number of species seems to have remained stable. Hagmeier \& Kändler (1927) recorded 54 species gathered from 22 grab samples and 5 dredge hauls. We found 89 species in 123 grabs

Table 1. Most abundant macrobenthic species in the subtidal Wadden Sea at Sylt during the period 1923-1926 and in 1980. Three sites, Ellenbogen, Huntje and the transect have been pooled in equal proportions and individuals $\cdot \mathrm{m}^{-2}(\mathrm{~N})$ are presented

\begin{tabular}{|lrlr|}
\hline \multicolumn{1}{|c|}{$1923-1926$} & N & \multicolumn{1}{c|}{1980} & N \\
\hline Balanus crenatus & 520 & Balanus crenatus & 2300 \\
Sabellaria spinulosa & 250 & Mytilus edulis & 1988 \\
Corophium bonelli & 105 & Scoloplos armiger & 226 \\
Scoloplos armiger & 29 & Cerastoderma edule & 164 \\
Abra alba & 17 & Heteromastus filiformis & 116 \\
Eumida sanguinea & 17 & Nereis virens & 62 \\
Ericthonius difformis & 14 & Pholoe minuta & 58 \\
Caprella linearis & 10 & Capitella capitata & 30 \\
\hline
\end{tabular}


and 50 dredge hauls. Converted to their sampling effort, we obtained 49 species. This is close to the 54 recorded by Hagmeier \& Kändler. Thus, the increase in species density is caused by a more even distribution of the species in 1980.

\section{Transect along the slope of Lister Ley}

Since the $1920 \mathrm{~s}$, the benthos on the slope of Lister Ley has changed considerably (Fig. 2, Table 2). In the Zostera bed on the upper part of the slope, Hagmeier \& Kändler found dense populations of amphipods, snails and young starfish. Endobenthic bivalves settled all along the slope. Sabellaria reefs on the lower slope were populated by polychaetes, amphipods and cnidarians. In 1980, Mytilus edulis occupied the upper half of the slope, while Balanus crenatus and many polychaetes were abundant along the entire range. Dense patches of Cerastoderma edule were observed at the three uppermost sites.

While Mollusca and Crustacea have decreased in species number and diversity since the 1920s, Polychaeta have increased (Table 3). Each site on its own shows little similarity in 1980 to the faunal composition recorded by Hagmeier \& Kändler (Fig. 4). Few species common to both investigations were found. Sites with a high number of species in 1923-26 (sites $1,2,7,8$ ) were the grass bed and the reefs. Sites with a high number of species in 1980 are dominated by $M$. edulis (sites 2 and 6). In Figure 4, dendrograms at sites 1,7 and 8 separate the sample obtained by Hagmeier \& Kändler from all recent ones. At the other sites, some degree of similarity is brought about mainly by spatial heterogeneity. Rather than having species in common, samples within subgroups lack many species otherwise present.

\section{Past oyster beds - mussel banks today}

The constancy of large epibenthic species was estimated from dredge hauls (Table 4). Of the 5 species abundant in 1923-26 but absent in 1980, Lepidochitona cinerea and Psammechinus miliaris are known to be still present in the area, while the other three are probably gone. A definite increase is substantiated for Mytilus edulis and Conopeum reticulum. The latter was mentioned by Hagmeier \& Kändler for some areas south of Sylt only. Large sized predators and scavengers do not seem to be affected in their constancy by the changed composition in the benthic community.

Most of the former oyster beds are covered by clusters of mussels today. As a consequence, grab samples taken during 1924-26 and those in 1980 contain quite different sets of species or at least different abundances where the same species did persist (Table 5). Ostrea edulis has vanished from the area. It was abundant prior to 1874 when yields of the oyster fishery dropped dramatically (Möbius, 1893; Hagmeier \& Kändler, 1927), remaining at a low level over a period of 50 years; and since 1925, oyster fishing became so unprofitable that it was finally abandoned (Reise, 1980). To our knowledge, no live specimen has been dredged during the last 30 years.

While mussels are a permanent component of the subtidal benthos, the population of Cerastoderma edule at Ellenbogen did not persist. Many were already tied together by byssus threads of $M$. edulis which settled on top of the cockles. One year later, in 1981, $C$. edule was rare at the site but empty shells were abundant within clusters of mussels. 


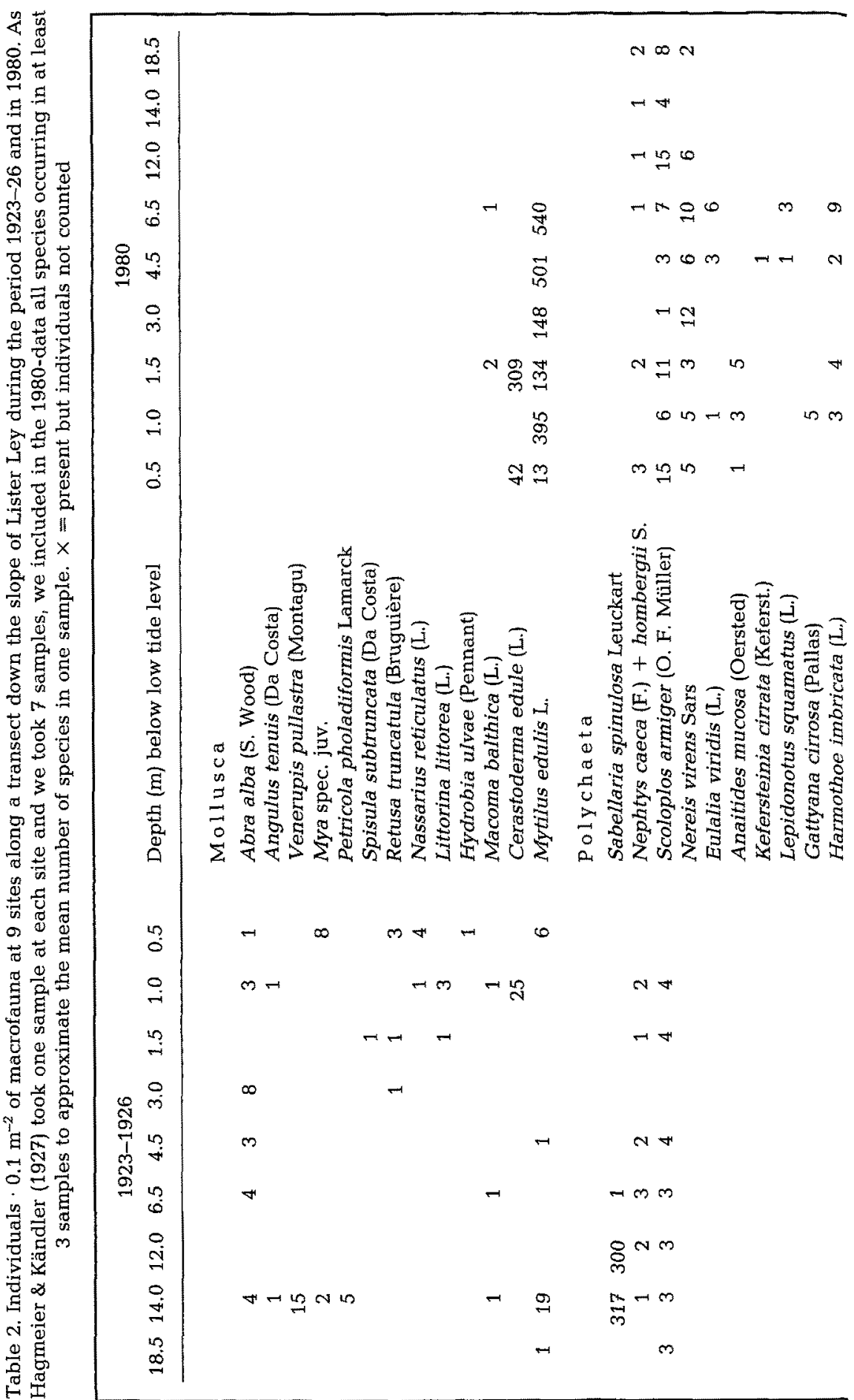




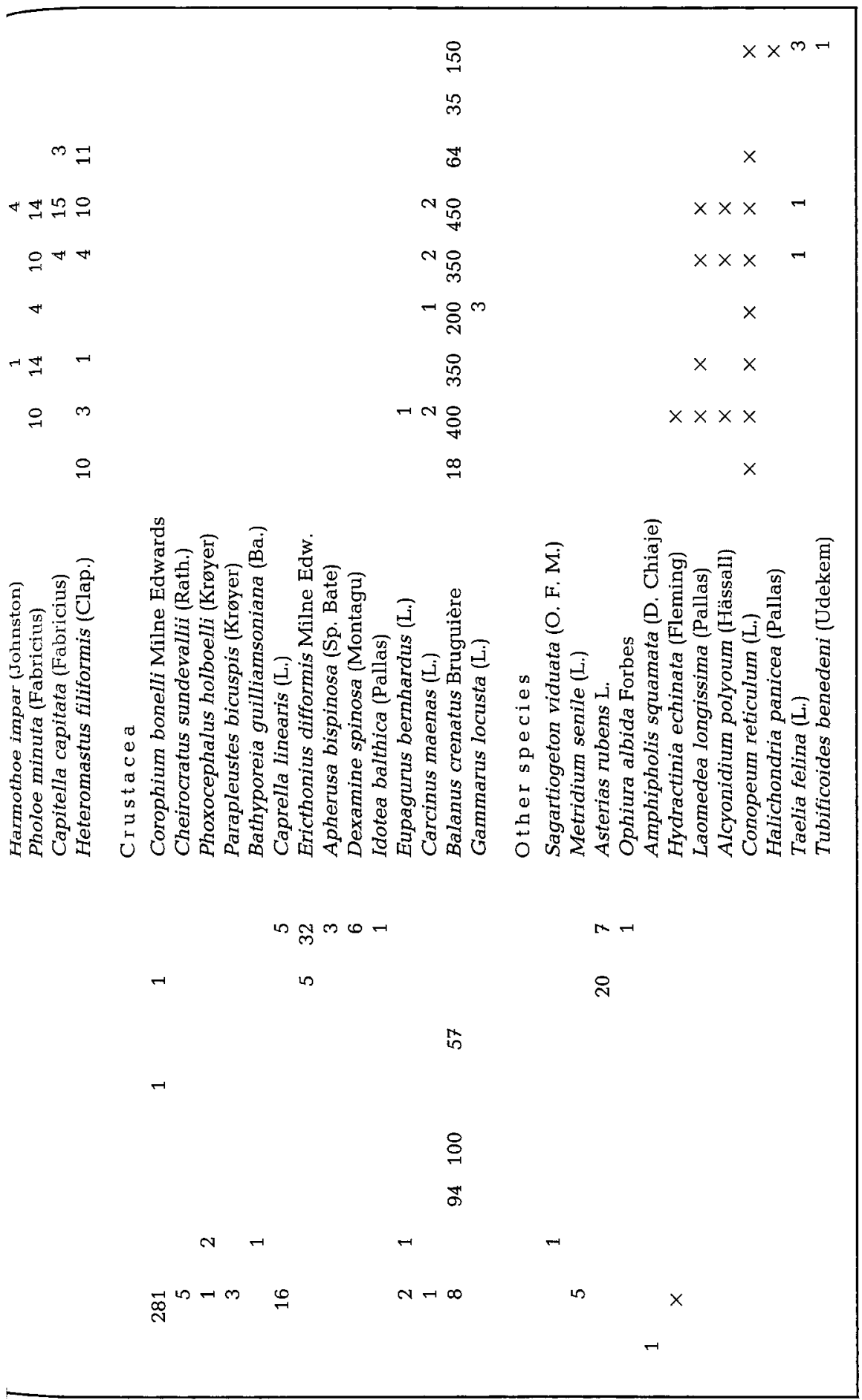


Table 3. Numerical characteristics of major taxa occurring along the transect down the slope of Lister Ley during the period 1923-26 and in 1980. All 9 stations have been combined to $0.9 \mathrm{~m}^{2}$ samples, and the data given refer to this sample size. $H^{\prime}=-\Sigma p_{i} \cdot \ln p_{i i} D=\left(\Sigma p_{i}^{2}\right)^{-1} ; F=(D-1) /$

$\left(\exp H^{\prime}-1\right)$

\begin{tabular}{|c|c|c|c|c|c|c|}
\hline \multirow{2}{*}{$\begin{array}{c}\text { Major taxa } \\
\text { Survey }\end{array}$} & \multicolumn{2}{|c|}{ Mollusca } & \multicolumn{2}{|c|}{ Polychaeta } & \multicolumn{2}{|c|}{ Crustacea } \\
\hline & $1923-26$ & 1980 & $1923-26$ & 1980 & 1923-26 & 1980 \\
\hline Number of individuals & 101 & 2110 & 653 & 294 & 826 & 2028 \\
\hline Number of species & 12 & 3 & 3 & 13 & 14 & 4 \\
\hline Shannon-Weaver diversity $H^{\prime}$ & 2.05 & 0.48 & 0.24 & 2.13 & 1.10 & 0.04 \\
\hline Simpson's diversity $D$ & 6.04 & 1.42 & 1.11 & 6.82 & 2.33 & 1.01 \\
\hline Hill's evenness $F$ & 0.74 & 0.68 & 0.41 & 0.78 & 0.66 & 0.27 \\
\hline
\end{tabular}

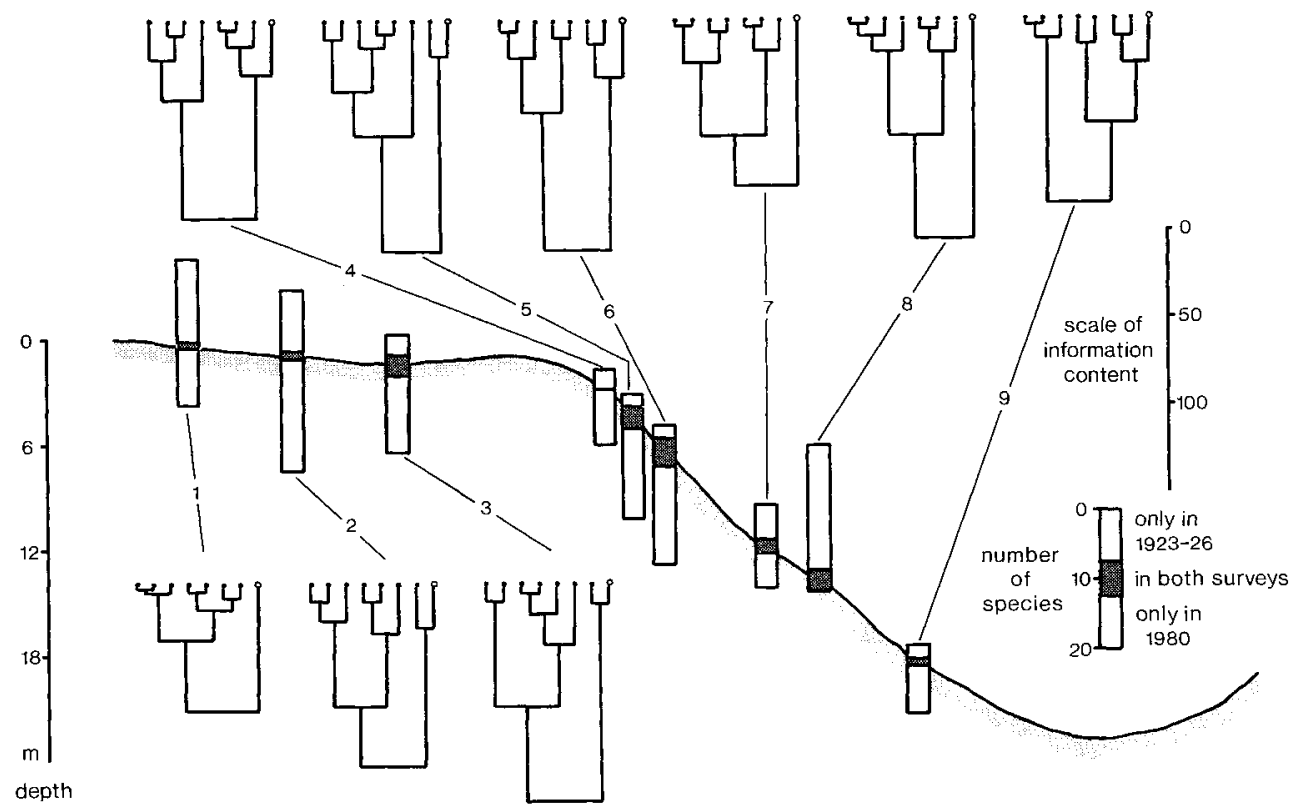

Fig. 4. Similarity of macrofauna between 1923-1926 and 1980 for 9 sites at the slope of Lister Ley. Dendrograms depict similarity between our sets of 7 samples $(\cdot)$ and the single ones taken by Hagmeier \& Kändler (o), calculated from presence-absence data according to Williams et al. (1966). The scale is given to the right. Vertical bars along the transect present numbers of species in both surveys and those occurring only once (see explanations to the right). For comparison with the single samples of the first survey, we included all species occurring in at least 3 out of 7 samples

With regard to polychaetes, only few species were more abundant in the early survey. In 1980, numbers of small as well as large sized species (i. e. Polynoidae, Nereis virens) were considerably higher. Many of them being abundant on the adjacent tidal flats too. In Crustacea, increased numbers of barnacles represent the major difference between the surveys. In large-sized decapods no changes are apparent. High numbers of 
Table 4. Frequencies (\%) of large macrobenthos and epigrowth caught with the dredge during the period 1923-1926 (5 "representative" hauls) and in 1980 (50 hauls). Because of ambiguities in Hagmeier \& Kändler's data, Hydractinia echinata, Crangon crangon, Balanus crenatus and fishes are excluded from the comparisons made

\begin{tabular}{|lcc|}
\hline \multicolumn{1}{|c|}{ Species } & $1923-26$ & 1980 \\
\hline Sertularia cupressina L. & 100 & 0 \\
Sagartiogeton viduata (O. F. Müller) & 100 & 0 \\
Ostrea edulis L. & 100 & 0 \\
Lepidochitona cinerea (L.) & 100 & 0 \\
Psammechinus miliaris (Gmelin) & 100 & 0 \\
Hyas araneus (L.) & 100 & 38 \\
Macropipus holsatus (Fabricius) & 80 & 46 \\
Lepidonotus squamatus (L.) & 100 & 74 \\
Alcyonidium 2 spp. & 100 & 74 \\
Taelia felina (L.) & 80 & 62 \\
Asterias rubens L. & 100 & 82 \\
Buccinum undatum L. & 80 & 72 \\
Eupagurus bernhardus (L.) & 100 & 90 \\
Carcinus maenas (L.) & 80 & 94 \\
Mytilus edulis L. & 40 & 100 \\
Conopeum reticulum (L.) & 0 & 100 \\
\hline
\end{tabular}

Table 5. Individuals $\cdot \mathrm{m}^{-2}$ of macrofauna at Ellenbogen $(\mathrm{E})$ and Huntje $(\mathrm{H})$ during 1924-1926 ( $\mathrm{n}=9+4$ grabs) and in 1980 ( $\mathrm{n}=30+30$ grabs). In the 1980-data all species are included which occurred in at least 4 or 3 samples to approximate the mean number of species in 9 or 4 samples respectively. Hagmeier \& Kändler (1927) did not differentiate between species of Nephtys thus we lumped them together too. $\mathrm{x}=$ present but individuals not counted

\begin{tabular}{|c|c|c|c|c|}
\hline \multirow{2}{*}{$\begin{array}{c}\text { Survey } \\
\text { Sites }\end{array}$} & \multicolumn{2}{|c|}{$1924-26$} & \multicolumn{2}{|c|}{1980} \\
\hline & $\mathrm{E}$ & $\mathrm{H}$ & E & $\mathrm{H}$ \\
\hline \multicolumn{5}{|l|}{ Mollusca } \\
\hline Lepidochitona cinerea (L.) & 3 & 3 & & \\
\hline Abra alba (S. Wood) & 1 & 25 & & \\
\hline Spisula subtruncata (Da Costa) & & 3 & & \\
\hline Ostrea edulis L. & 1 & & & \\
\hline Petricola pholadiformis Lamarck & 1 & & & \\
\hline Venerupis pullastra (Montagu) & 0.2 & & & \\
\hline Mya spec. juv. (truncata?) & 1 & & & \\
\hline Buccinum undatum $\mathrm{L}$. & 1 & 3 & 1 & \\
\hline Cerastoderma edule (L.) & & & 117 & \\
\hline Macoma balthica (L.) & & & 14 & 8 \\
\hline Mytilus edulis $\mathrm{L}$. & & & 2804 & 1425 \\
\hline \multicolumn{5}{|l|}{ Polychaeta } \\
\hline Gattyana cirrosa (Pallas) & 15 & 3 & & \\
\hline Sabellaria spinulosa Leuckart & & 5 & & \\
\hline Ampharete acutifrons (Grube) & & 5 & & 1 \\
\hline Eumida sanguinea (Oersted) & 50 & 3 & 2 & 2 \\
\hline Lanice conchilega (Pallas) & 31 & & 4 & \\
\hline
\end{tabular}


Table 5 (continued)

\begin{tabular}{|c|c|c|c|c|}
\hline \multirow{2}{*}{$\begin{array}{c}\text { Survey } \\
\text { Sites }\end{array}$} & \multicolumn{2}{|c|}{$1924-26$} & \multicolumn{2}{|c|}{1980} \\
\hline & E & $\mathrm{H}$ & E & $\mathrm{H}$ \\
\hline Pectinaria koreni Malmgren & 3 & & 2 & \\
\hline Nephtys caeca $+N$. hombergii & & 17 & $\overline{9}$ & 21 \\
\hline Scoloplos armiger (O. F. Müller) & 32 & 27 & 118 & 483 \\
\hline Lepidonotus squamatus (L.) & 1 & & 24 & 10 \\
\hline Harmothoe imbricata (L.) & & & 39 & 11 \\
\hline Harmothoe impar (Johnston) & & & 24 & 13 \\
\hline Pholoe minuta (Fabricius) & & & 90 & 78 \\
\hline Heteromastus filiformis (Clap.) & & & 198 & 110 \\
\hline Capitella capitata (Fabricius) & & & 56 & 6 \\
\hline Nereis virens Sars & & & 103 & 34 \\
\hline Eulalia viridis (L.) & & & 26 & 4 \\
\hline Eteone longa (Fabricius) & & & 3 & 4 \\
\hline Anaitides mucosa (Oersted) & & & 3 & 3 \\
\hline Kefersteinia cirrata (Keferst.) & & & 6 & \\
\hline Malacoceros tetracerus (Schmarda) & & & 3 & 11 \\
\hline Malacoceros fuliginosus (Clap.) & & & 2 & \\
\hline Tharyx marioni (Saint-Joseph) & & & 2 & 3 \\
\hline Spio filicornis (O. F. Müller) & & & 5 & \\
\hline Pygospio elegans (Claparède) & & & 7 & 3 \\
\hline \multicolumn{5}{|l|}{ Crustacea } \\
\hline Cheirocratus sundevallii (Rath.) & 14 & 12 & & \\
\hline Caprella linearis (L.) & & 7 & & \\
\hline Apherusa bispinosa (Sp. Bate) & 1 & & & \\
\hline Dexamine spinosa (Montagu) & 1 & & & \\
\hline Bodotria scorpioides (Montagu) & 1 & & & \\
\hline Macropipus holsatus (Fabricius) & 18 & & 1 & \\
\hline Eupagurus bernhardus (L.) & 15. & 3 & 5 & 2 \\
\hline Crangon crangon (L.) & 1 & 7 & 1 & 7 \\
\hline Carcinus maenas (L.) & 11 & & 48 & 9 \\
\hline Balanus crenatus Bruquière & 800 & 260 & 4000 & 1000 \\
\hline Hyas araneus (L.) & & & 7 & \\
\hline Corophium bonelli Milne Edwards & & & 4 & \\
\hline Gammarus locusta (L.) & & & & 6 \\
\hline Bathyporeia sarsi Watkin & & & & 24 \\
\hline \multicolumn{5}{|l|}{ Otherspecies } \\
\hline Sagartiogeton viduata (O. F. Müller) & 6 & & & \\
\hline Metridium senile (L.) & 1 & & & \\
\hline Psammechinus miliaris (Gmelin) & 6 & & & \\
\hline Asterias rubens L. & 1 & & & \\
\hline Ophiura albida Forbes & 1 & & & \\
\hline Sertularia cupressina L. & & $x$ & & \\
\hline Hydractinia echinata (Fleming) & $x$ & $x$ & $x$ & $x$ \\
\hline Taelia felina (L.) & & & 5 & 5 \\
\hline Laomedea longissima (Pallas) & & & $x$ & \\
\hline Laomedea flexuosa Alder & & & $x$ & \\
\hline Alcyonidium polyoum (Hässall) & & & $x$ & $x$ \\
\hline Conopeum reticulum (L.) & & & $x$ & $x$ \\
\hline Tubificoides benedeni (Udekem) & & & 3 & 1 \\
\hline
\end{tabular}


these species include juveniles in both sets of samples. The herbivor Hyas araneus was absent from the grab samples during 1924-26 but occurred in almost all dredges at that time.

Because of all these differences in species composition and species abundance, numerical parameters of the benthic assemblage also changed from the early survey to the recent one (Table 6). In all major taxa reported the total number of individuals increased, and in polychaetes species richness is much higher in 1980. Diversity and evenness decreased in Mollusca and Crustacea, while in Polychaeta there was an increase in diversity at Ellenbogen.

Table 6. Numerical characteristics of major taxa occurring at Ellenbogen $(E)$ and Huntje $(H)$ during the period 1924-1926 and in 1980. Number of species refer to 9 grabs at $E$ and 4 grabs at $H$. See also Table 3

\begin{tabular}{|c|c|c|c|c|c|c|c|}
\hline \multirow{2}{*}{$\begin{array}{c}\text { Major taxa } \\
\text { Survey }\end{array}$} & & \multicolumn{2}{|c|}{ Mollusca } & \multicolumn{2}{|c|}{ Polychaeta } & \multicolumn{2}{|c|}{ Crustacea } \\
\hline & & $1924-26$ & 1980 & $1924-26$ & 1980 & $1924-26$ & 1980 \\
\hline Individuals $\cdot \mathrm{m}^{-2}$ & $\begin{array}{l}E \\
H\end{array}$ & $\begin{array}{r}8 \\
34\end{array}$ & $\begin{array}{l}2936 \\
1433\end{array}$ & $\begin{array}{r}133 \\
60\end{array}$ & $\begin{array}{l}726 \\
628\end{array}$ & $\begin{array}{l}862 \\
289\end{array}$ & $\begin{array}{l}4066 \\
1048\end{array}$ \\
\hline Number of species & $\begin{array}{l}\mathrm{E} \\
\mathrm{H}\end{array}$ & $\begin{array}{l}6 \\
4\end{array}$ & $\begin{array}{l}4 \\
2\end{array}$ & $\begin{array}{l}7 \\
6\end{array}$ & $\begin{array}{l}22 \\
18\end{array}$ & $\begin{array}{l}9 \\
5\end{array}$ & $\begin{array}{l}7 \\
6\end{array}$ \\
\hline Shannon-Weaver diversity $H^{\prime}$ & $\begin{array}{l}E \\
H\end{array}$ & $\begin{array}{l}1.67 \\
0.87\end{array}$ & $\begin{array}{l}0.20 \\
0.03\end{array}$ & $\begin{array}{l}1.46 \\
1.43\end{array}$ & $\begin{array}{l}2.23 \\
1.46\end{array}$ & $\begin{array}{l}0.37 \\
0.45\end{array}$ & $\begin{array}{l}0.10 \\
0.25\end{array}$ \\
\hline Simpson's diversity $D$ & $\begin{array}{l}E \\
H\end{array}$ & $\begin{array}{l}4.57 \\
1.77\end{array}$ & $\begin{array}{l}1.09 \\
1.01\end{array}$ & $\begin{array}{l}3.75 \\
3.31\end{array}$ & $\begin{array}{l}6.71 \\
2.45\end{array}$ & $\begin{array}{l}1.16 \\
1.23\end{array}$ & $\begin{array}{l}1.03 \\
1.10\end{array}$ \\
\hline Hill's evenness $F$ & $\begin{array}{l}E \\
H\end{array}$ & $\begin{array}{l}0.83 \\
0.56\end{array}$ & $\begin{array}{l}0.41 \\
0.37\end{array}$ & $\begin{array}{l}0.83 \\
0.73\end{array}$ & $\begin{array}{l}0.69 \\
0.44\end{array}$ & $\begin{array}{l}0.36 \\
0.41\end{array}$ & $\begin{array}{l}0.29 \\
0.34\end{array}$ \\
\hline
\end{tabular}

\section{Species associated with mussels}

Mytilus edulis gave the past oyster beds their new structure. Clusters of mussels accumulate silt, provide shelter for other species and surfaces for epigrowth. At the sites Ellenbogen and Huntje, 60 grab samples were taken in 1980 containing variable amounts of mussels. Out of the 12 most frequently sampled species, 7 are positively correlated with the number of mussels present (Table 7). B. crenatus is an abundant epigrowth on mussels, while polychaetes will profit from shelter and accumulated silt. There is a significant positive correlation of the total number of polychaetes, the number of polychaete species and their diversity with mussel density. Thus, the considerable increase in polychaetes since the survey of 1923-26 may be a consequence of the spread in $M$. edulis. However, not all polychaete species abundant in 1980 are correlated with mussel density and the genus Nephtys shows a negative correlation.

\section{DISCUSSION}

On comparing the results of the two surveys, a trend towards a massive long-term increase of the mussel banks and associated species, particularly polychaetes and 
Table 7. Abundance of macrofaunal species at Ellenbogen and Huntje as functions of mussel abundance (Mytilus edulis). Linear regressions calculated from $\mathrm{n}=60$ grab samples taken in July 1980. Individuals $\cdot 0.1 \mathrm{~m}^{-2}=a+b\left(\right.$ Mytilus $\left.\cdot 0.1 \mathrm{~m}^{-2}\right) . a, b=$ coefficients, * indicates significance

$(P<0.05)$ of the correlation coefficient $r$. All species present in at least 20 samples are listed

\begin{tabular}{lccc|}
\hline \multicolumn{1}{c}{ Species } & $a$ & $b$ & $r$ \\
\hline Lepidonotus squamatus & 0.033 & +0.008 & $+0.732^{*}$ \\
Eulalia viridis & 0.190 & +0.006 & $+0.714^{*}$ \\
Nereis virens & 2.426 & +0.021 & $+0.705^{*}$ \\
Balanus crenatus & 62.967 & +0.835 & $+0.702^{*}$ \\
Harmothoe imbricata & 0.682 & +0.009 & $+0.686^{*}$ \\
Pholoe minuta & 4.237 & +0.020 & $+0.541^{*}$ \\
Heteromastus filiformis & 7.004 & +0.040 & $+0.441^{*}$ \\
Carcinus maenas & 1.743 & +0.005 & +0.245 \\
Capitella capitata & 1.681 & +0.004 & +0.239 \\
Harmothoe impar & 1.318 & +0.003 & +0.198 \\
Scoloplos armiger & 22.347 & -0.006 & -0.118 \\
Nephtys 2 spp. & 1.976 & -0.002 & $-0.303^{*}$ \\
\hline
\end{tabular}

barnacles becomes evident. Species richness in molluscs, as well as the abundance of some amphipods associated with seagrass and Sabellaria reefs decreased. In contrast, large epibenthic predators and scavengers could hold their position.

To what extent may the claimed long-term differences result from artifacts or unequal sampling efficiency? For dredging we used exactly the same device as Hagmeier \& Kändler (1927) did, trawling for $10 \mathrm{~min}$ and about $1000 \mathrm{~m}$. Although Hagmeier \& Kändler present numbers of individuals encountered in a trawl assumed to be "typical" for a given site, we confined our comparison to presence-absence data. Thus, efficiency in catching large epibenthic invertebrates is not considered to be different in the two surveys.

Instead of using a Petersen grab as Hagmeier \& Kändler did, we had to use a Van Veen grab of the same size. Particularly on sandy bottoms the latter collects more sediment and the biting profiles are slightly different (Gallardo, 1965; Ziegelmeier, 1968). However, currents, waves, and experience in handling the grab are variables of equal importance. On average, 51 of sediment were obtained with both grabs, and where a sample contained less it was rejected. The mesh of sieves was equal but the sorting procedures differed. Hagmeier \& Kändler picked up the organisms directly out of the sieves. Because this takes some time, slender worms have a good chance to escape. In 1980 we did the sorting in dishes at the lab and thus probably worked with higher efficiency regarding some polychaetes such as Spionidae, Capitellidae and Orbiniidae. On the other hand, differences in sorting efficiency cannot account for an increase in such large sized polychaetes as Lepidonotus squamatus, Harmothoe spp., Eulalia viridis and Nereis virens. While improved sorting affects our estimates on polychaete abundance, it will hardly alter the number of species encountered, as we do not report on species smaller than those listed by Hagmeier \& Kändler.

Severe winters are known to have lasting effects on benthic macrofauna in the North Sea (Smidt, 1944; Ziegelmeier, 1964, 1970; Dörjes, 1980; Reichert \& Dörjes, 1980; Buhr, 1981). Ziegelmeier (1978) noted a general shift from dominance of molluscs to domi- 
nance of polychaetes in the years following a very cold winter. As such a shift is claimed to be one of the major long-term trends in the present study, the sequence of severe winters throughout the period of concern is worth recording: 1923/24, 1928/29, 1939/40, $1940 / 41,1941 / 42,1946 / 47,1955 / 56,1962 / 63,1969 / 70$ and 1978/79. There is no trend in frequency or amplitude, and both surveys are conducted subsequent to a particularly cold winter. Thus, winter effects cannot account for the differences observed but the possibility of population fluctuations triggered off by other environmental factors in the course of decades cannot be ruled out. Unfortunately, we have no reliable long-term data on physical factors in the study area. More frequent surveys in the future are needed to test our conclusions.

Are all the proposed long-term changes ultimately caused by human interference? Oyster beds, once common in the shallow parts of the North Sea are absent from the German Bight today. There has been some debate as to the actual cause of the decline (Möbius, 1877; Hagmeier \& Kändler, 1927) but more recent accounts on the subject leave little doubt that overexploitation by oyster fishery is responsible for the extinction of Ostrea edulis in the area considered here (Linke, 1937; Korringa, 1980; Reise, 1980, 1982).

In the Wadden Sea, oyster beds were intermediate in the vertical distribution between mussel banks above and Sabellaria reefs below, and both tended to invade the oyster beds (Hagmeier \& Kändler, 1927; Linke, 1937). At Sylt, the entire range of the former oyster beds is now occupied by mussel banks. It is not known whether this occurred with or without the aid of the mussel fishery. In any case, since the $1950 \mathrm{~s}$ subtidal banks have been stocked with spat, dredged from tidal flats. Today, there are more extensive banks even in the intertidal zone at Sylt than were recorded in 1934 by Wohlenberg (1937). The intertidal banks are of no interest to sea fisheries. There may very well be a natural component in the spread of Mytilus edulis but fisheries certainly promoted this trend.

Sabellaria reefs are completely lost to the area. Local fishermen claim to have ground them with heavy gear because the reefs ripped apart the nets when fishing for shrimp. There is no other evidence. The loss of an extensive subtidal seagrass bed of the large growth form of Zostera marina L. during the general epidemic seagrass disease (1933-34) is regarded as a natural event (Wohlenberg, 1935; Den Hartog, 1970). As in the Dutch western Wadden Sea, $Z$. marina failed to reestablish itself in the subtidal zone of our study area. Van den Hoek et al. (1979) suppose that increased turbidity following the closure of the Zuiderzee in 1932 prevented recolonization in the Dutch western Wadden Sea. For the Sylt area, we have no data on turbidity but dams connecting the Island of Sylt (since 1927) and the Island of Rømø (since 1948) with the mainland are likely to have similar effects as the closure of the Zuiderzee. Taken together, there is little doubt that all major habitat shifts were caused, promoted or made permanent by human interference.

In recent years, a number of species immigrated into the tidal flats of the Wadden Sea (reviewed by Michaelis, 1978, 1981) without any apparent environmental cause, i.e. at Sylt Tharyx marioni (Saint-Joseph), Spio filicornis (O. F. Müller) and Chelon lambrosus (Risso). Recent gains and losses of species in the Wadden Sea give no evidence of any directional change in climate.

Long-term comparisons similar to the present study have been conducted by Ceder- 
wall \& Elmgren (1980) and Persson (1981) in the Baltic Sea. They noted a considerable increase in the biomass of benthic macrofauna which the former attribute to recent eutrophication while the latter assumes decreased predation pressure following exploitation of flatfish. Also at Sylt, an increase in biomass must be assumed as a consequence of increased abundance in such large species as Mytilus edulis and Nereis virens. In this area, however, we assume the spread of mussel banks promoted by fisheries to be the principle cause of increased biomass. Predators on bivalves (Carcinus maenas, Asterias rubens) do not seem to be less abundant today than 55 years ago.

It is well known that most terrestrial communities have been severely altered by man's impact. Here we point out that the same applies to the coastal sea. The present assemblage of organisms is not the pure outcome of a natural chain of events. Thus, there is no reason to expect a stable balance between trophic levels, brought about by coevolution. The present state is apt to continuous change not only because of man's continued interference but because the relative abundances are to a high degree artificial.

Acknowledgements. We are grateful to the crew of R. V. "Mya", N. Kruse and P. Elbert, for handling so skillfully our sampling gear. The Biologische Anstalt Helgoland, Litoralstation List, generously provided ship and laboratory facilities. Dr. E. Ziegelmeier kindly gave substantial advice.

\section{LITERATURE CITED}

Buhr, K.-J., 1981. Auswirkungen des kalten Winters 1978/79 auf das Makrobenthos der LaniceSiedlung im Weser-Ästuar. - Veröff. Inst. Meeresforsch. Bremerhaven 19, 115-131.

Cederwall, H. \& Elmgren, R., 1980. Biomass increase of benthic macrofauna demonstrates eutrophication of the Baltic Sea. - Ophelia (Suppl.) 1, 287-304.

Dörjes, J., 1980. Auswirkungen des kalten Winters 1978/1979 auf das marine Makrobenthos. Natur Mus., Frankf. 110, 109-115.

Gallardo, V. A., 1965. Observations on the biting profiles of three $0.1 \mathrm{~m}^{2}$ bottom-samplers. Ophelia 2, 319-322.

Hagmeier, A., 1925. Vorläufiger Bericht über die vorbereitenden Untersuchungen der Bodenfauna der Deutschen Bucht mit dem Petersen-Bodengreifer, - Ber. dt. wiss. Kommn Meeresforsch. $1,247-272$.

Hagmeier, A., \& Kändler, R., 1927. Neue Untersuchungen im nordfriesischen Wattenmeer und auf den fiskalischen Austernbänken. - Wiss. Meeresunters. (Helgoland) 16, 1-90.

Hartog, C. den, 1970. The seagrasses of the world. - Verh. K. ned. Akad. Wet. (Afd. Natuurk., 2. R.) $59,1-275$.

Hoek, C. van den, Admiraal, W., Colijn, F., \& De Jonge, V. N., 1979. The role of algae and seagrasses in the ecosystem of the Wadden Sea: A review. - In: Flora and vegetation of the Wadden Sea. Ed. by W. J. Wolff. Balkema, Rotterdam, 9-118. (Rep. Wadden Sea Working Group 3.)

Korringa, P., 1980. Management of marine species. - Helgoländer Meeresunters. 33, 641-661.

Linke, O, 1937. Der Verfall der Wangerooger Austernbänke. - Abh. naturw. Ver. Bremen 30, 238-241.

Michaelis, H., 1978. Recent biological phenomena in the German Waddensea. - Rapp. P.-v. Réun. Cons. perm. int. Explor. Mer 172, 276-277.

Michaelis, H., 1981. Recent changes in the communities of the Wadden Sea - natural phenomena or effects of pollution? - Biol. Meddr 5, 87-95.

Möbius, K., 1877. Die Auster und die Austernwirthschaft. Wiegandt, Hempel \& Parey, Berlin, $126 \mathrm{pp}$. 
Möbius, K., 1893. Über die Tiere der schleswig-holsteinischen Austernbänke, ihre physikalischen und biologischen Lebensverhältnisse. - Sber. preuss. Akad. Wiss. 7, 33-58.

Persson, L.-E., 1981. Were macrobenthic changes induced by thinning out of flatfish stocks in the Baltic Proper? - Ophelia 20, 137-152.

Reichert, A., \& Dörjes, J, 1980. Die Bodenfauna des Crildumersieler Wattes (Jade, Nordsee) und ihre Veränderung nach dem Eiswinter 1978/79. - Senckenberg. marit. 12, 213-245.

Reise, K., 1980. Hundert Jahre Biozönose. - Naturw. Rdsch., Stuttg. 33, 328-335.

Reise, K., 1982. Long-term changes in the macrobenthic invertebrate fauna of the Wadden Sea: Are polychaetes about to take over? - Neth. J. Sea Res. 16 (in press).

Smidt, E. L. B., 1944. The effects of ice winters on marine littoral faunas. - Folia geogr. dan. 2 (3), $1-36$.

Williams, W. T., Lambert, J. M., \& Lance, G. N., 1966. Multivariate methods in plant ecology V. Similarity analysis and information analysis. - J. Ecol. 54, 427-445.

Wohlenberg, E., 1935. Beobachtungen über das Seegras, Zostera marina L., und seine Erkrankung im nordfriesischen Wattenmeer. - Nordelbingen 11, 1-19.

Wohlenberg, E., 1937. Die Wattenmeer-Lebensgemeinschaften im Königshafen von Sylt. - Helgoländer wiss. Meeresunters, 1, 1-92.

Ziegelmeier, E., 1964. Einwirkungen des kalten Winters 1962/63 auf das Makrobenthos im Ostteil der Deutschen Bucht. - Helgoländer wiss. Meeresunters. 10, 276-282.

Ziegelmeier, E., 1968. Makrobenthos. - In: Methoden der meeresbiologischen Forschung. Hrsg. von C. Schlieper. VEB Fischer, Jena, 97-108.

Ziegelmeier, E., 1970. Uber Massenvorkommen vierschiedener makrobenthaler Wirbelloser während der Wiederbesiedlungsphase nach Schädigungen durch "katastrophale ${ }^{*}$ Umwelteinflüsse, - Helgoländer wiss. Meeresunters. 21, 9-20.

Ziegelmeier, E., 1978. Macrobenthos investigations in the eastern part of the German Bight from 1950 to 1974. - Rapp. P.-v. Réun. Cons. perm. int. Explor. Mer 172, 432-444. 